\title{
Measuring The Theoretical Paradigm Shift From Marketing Mix To Relational Marketing
}

Dean R. Manna (E-mail: manna@rmu.edu), Robert Morris University Alan D. Smith (E-mail: smitha@rmu.edu), Robert Morris University

\begin{abstract}
Much has been written in the recent marketing literature on the perceived importance of moving from a transaction basis to a long-term relationship basis in terms of personal selling. Since the traditional marketing mix paradigm has dominated marketing philosophy for so long, many perceive there is a marketing shift, especially in service marketing, to the relational marketing paradigm. A sales force from five industries, representing primarily service industries $(n=142)$, were tested on a number of statistical techniques including correlations, stepwise regression, and n-way ANOVA, and yielded no significant trend to support the theoretical paradigm shift.

KEY WORDS: Relational marketing, marketing paradigms.
\end{abstract}

\section{Introduction}

Current marketing trends have revealed, "Relationship marketing is a hot topic with both academic researchers and practitioners" (Garver and Gardial, 1996, p. 243). The interactions in the relationship marketing paradigm that frequently occur among the various service providers and business-to-customers (B2C) as well as among the various players with a companies somewhat transparent supply chain or business-to-business (B2B) in an e-commerce environment can be structured such that the provider and recipient may be well known or strangers to each other (Gutek, 1995, 1997). Gutek, Bhappu, Liao-Troth, and Cherry (1999) contend that service interactions can be categorized into three distinct interaction types: relationships, pseudo-relationships, and encounters. According to Gutek, Cherry, Bhappu, Schneider, and Woolf (2000), these distinctions in relationship marketing are possible based on the following aspects of the service experience:

1. Can the provider and customer identify the specific individual with whom they interacted?

2. Do the provider and customer expect to interact in the future?

3. Is there a history of shared interactions?

As suggested by Gutek et al., the answers to these questions can "help identify the type of service interaction in play for every dyadic service interaction between a customer and provider" (p. 319). Many consider the relational marketing -- basically building long-term relationships and management with clients - as the leading new approach to marketing (Dwyer, Shurr, and Oh, 1987; Gummesson, 1987; Ingram, 1996; Jackson, 1985). "Several academic researchers feel that delivering customer value and satisfaction are key aspects of the development and maintenance of relational exchanges (Burger and Cann, 1995; Wilson, 1995; Woodruff and Gardial, 1995).

Obviously, sales managers in the field must formulate marketing strategies that deal with real issues that are not always anticipated in the academic environment. Frequently, it is the sales manager's perception of a dynamic market in flux and its continuing changing demands and requirements that play a major role in determining the criteria for a professional sales force. Of course, it is the sales force that would be first to detect a major shift in the marketing mix paradigm and know what area it has shifted to. As previously stated, many feel that the movement is away from product and application expertise and rapidly shifting to relational selling. Product support services are gaining importance as compared to product and price, and this trend is expected to continue (Garver and 
Gardial, 1996). Relational marketing is suggested as a raw marketing paradigm, and a number of important consequences for marketing and management of relationship-style strategies exist. However, before the push to establish the characteristics of this new paradigm, there should be enough empirical evidence collected in the field to verify that the shift has indeed occurred. Therefore, the primary purpose is to empirically test the theory that there is a detectable shift in the practitioners' perceptions from the traditional paradigm of marketing to relational marketing paradigm.

\section{Methodology}

Although in any study designed to test the outcomes of a relational model in service marketing, it is important to generalize across service areas as must as possible. Thus, in order to study several distinct service domains where sales managers are in a position to either give personal service or to obverse and possibly manage the relational paradigm process in the three processes as described by Gutek, Bhappu, Liao-Troth, and Cherry (1999) of relationships, encounters, or pseudo-relationships, the authors of the present study sought diversity. This diversity among service domains with respect to the qualifications, requirements, and skill level of the service manager were reflected in the type of industry (primarily service-oriented), such as computer, financial, sporting goods; shipping via e-commerce channels, and office equipment.

The frequency with which provider and customer interact, and the extent to which the customer can choose the service provider, all of which should enhance generalizability. If service relationships are qualitatively different from service encounters and pseudo-relationships, any differences should hold up across diverse situations. In order to meet these goals and test a number of specific hypotheses, an instrument was developed to measure sales force practitioners' perceptions of traditional marketing roles - product and applications expertise - and characteristics associated with the relational selling paradigm. Table 1 lists some of the important variables, which were derived from this instrument that was self-administered by 150 sales professionals associated with the metropolitan area of Pittsburgh, Pennsylvania. In some of the subsequent analysis, outliers and respondents with missing data were excluded from further analyses. A number of industries, primarily service in nature, were represented in the survey: office equipment (18), shipping services (33), sporting goods (11), financial services (57), and computer hardware (18).

A number of hypotheses that could be tested concerning the proposed relational marketing paradigm are listed as following:

H1: There is a perceived difference among the current marketing paradigm, as defined by reliance on product and application expertise roles, as opposed to the new approach on relational marketing by practicing sales professionals.

H2: There is a perceived difference among industries, educational levels, and years of experience with the traditional and emerging relational marketing paradigm.

These hypotheses can be statistically tested by using a combination of correlation analyses - both nonparametric Spearman Rank Correlation Coefficients and parametric Pearson Correlation Coefficients among the three approaches with selected variables - and n-way ANOVA to inspect difference among the approaches.

H3: If there is a shift in marking paradigms, then there should be a significant shift of sales performance, as measured by sales volume, from the traditional approaches of product and applications expertise to the emerging relationship-marketing paradigm.

The statistical technique to test this hypothesis is forward stepwise regression. Hopefully, the amount of explained variation as measured by significant $R^{2}$ change values will be significantly differentiated among the three approaches, as well as other performance and related variables with sales volume as the criterion. 


\section{Results And Discussion}

A number of statistical tables were generated in the course of testing the three major research hypotheses of the present study. Table 2 displays the two-way ANOVA measuring the importance of the traditional product expertise versus the applications and relational selling approaches, while Tables 3 and 4 compare the result of oneway analysis of product expertise versus application and relational marketing roles, respectively. Table 5 lists the multiple $R, R^{2}, R^{2-}$ change, and F-ratios for nine questionnaire variables as defined in the Table, including the three marketing strategies, with sales volume as the criteria. Lastly, Tables 6 and 7 illustrate the correlation analysis among the sales roles using Pearson and Spearman Correlation Coefficients, respectively.

Using the statistical data derived from these tables and applying them to the three research hypotheses, a number of interesting results concerning the theoretical paradigm shift can be derived. Of course, the present study is only an instant in time or snapshot of the professional sales force in one metropolitan area. However, it does shed some light on whether the paradigm shift is occurring as rapidly as many believe, if at all.

In term of the first hypothesis, there is no statistical evidence that there is a shift of perceived importance from the traditional paradigm, consisting of product and application expertise, with the emerging relational marketing paradigm. The two-way (Table 2) and one-way (Tables 3 and 4) main effects were not significant. Interestingly through, the applications expertise and relationship marketing approaches were found to be significantly interacting and acting as moderating variables in terms of importance to the efficiency of the overall sales force.

In terms of the second hypothesis, initial results were also equally disappointing. Perceived importance of relational marketing was weakly positively correlated with years of experience (Tables 6 and 7). No such statistical relationship existed for industrial type and levels of education. In fact, there were several correlations with the characteristics of the traditional paradigm that were found to be highly significant - PRODEXP with INDUS and EDUC.

The final hypothesis, dealing with sales volume as the criterion, should shed the most light on whether a true shift in paradigms occurred. Obviously, there should be a noticeable movement towards increasing levels of sales volume with relational marketing. At the very least, the approaches associated with the traditional paradigm should be significantly different in terms of captured $\mathrm{R}^{2-}$ change as compared to the $\mathrm{R}^{2}$ change explained by relational marketing. As evident from Table 5, product expertise captured slightly more variance with an $\mathrm{R}^{2}$ change of 0.02336 than relational marketing $\left(\mathrm{R}^{2}\right.$ change $\left.=0.01681\right)$. Surprisingly, the variance explained by the characteristics of the two paradigms was relatively meager. Years of experience $\left(R^{2}=0.05368\right)$ and Size of Sales force $\left(\mathrm{R}^{2}=0.04683\right)$ were more important factors in predicting volume than the perceived importance of professional selling activity.

\section{General Implications And Conclusions}

The concept of value-added in terms of various business activities, especially related to the marketing function of the firm, has been driving many of the reforms in academics for most of the past decade. Value and its ability to be measured are concerns of both practitioners and academic researchers alike. It is the basic premise of the emerging relational marketing paradigm that delivering customer value and satisfaction in exchange for relationships is key to developing, maintaining, and facilitating the overall buyer-seller equation, as opposed to the more traditional marketing-mix paradigm. In theory, relational marketing's philosophy of developing long-term client relationships for the ultimate goal of increasing user value-added is extremely tempting and utilizes common sense. However, at least within the limitations of the present study, little or no empirical evidence exists to support the theoretical paradigm shift towards relational marketing. Perhaps, relational marketing is really a sub-component of larger-scale movements of the value-added process; and, as such, it is extremely difficult to isolate its effects from a statistical viewpoint. Obviously, more empirical research must be completed before we, as marketing professionals, can truly say that a shift in marketing paradigms has occurred. 


\section{References}

1. Burger, P.C. and C. W. Cann. 1995. "Post purchase strategy: A key to successful industrial marketing and customer satisfaction." Industrial Marketing Manager 24: 91-98.

2. Dwyer, F. R., P. H. Shurr, and S. Oh. 1987. "Developing buyer and seller relationships." Journal of Marketing 51 (April): 11-27.

3. Garver, M.S. and S. F. Gardial. 1996. "The role of the salesperson in delivering customer value: A situational analysis." Proceedings of the Association of Marketing Theory and Practice 5:243-249.

4. Gummesson, E. 1987. "The new marketing - developing long-term interactive relationships." LongRange Planning 20: (4): 10-20.

5. Gutek, B. A. 1995. "The dynamics of service: Reflections on the changing nature of customer/provider interactions." San Francisco: Jossey-Bass.

6. Gutek, B. A. 1997. "Dyadic interaction in organizations." In C. L. Cooper and S. E. Jackson (Eds.), Creating tomorrow's organizations: A handbook for future research in organizational behavior. Chichester: Wiley.

7. Gutek, B. A., Bhappu, A. D., Liao-Troth, M. A., \& Cherry, B. 1999. "Distinguishing between service relationships and encounters." Journal of Applied Psychology, 84(2), 218-233.

8. Gutek, Barbara A.; Cherry, Bennett; Bhappu, Anita D.; Schneider, Sherry; Woolf, Loren. 2000. "Features of service relationships and encounters." Work \& Occupations. 27(3): 319-343. (August).

9. Ingram, T. N. 1996. "Relationship selling: Moving from rhetoric to reality." Mid-American Journal of Business 11(1): 5-13.

10. Jackson, B. B. 1985. "Build customer relationships that last." Harvard Business Review, 63 (Nov.-Dec.): 120-128.

11. Wilson, D. T. 1995. "An integrated model of buyer-seller relationships." Journal of the Academy of Marketing Science 23 (Fall): 335-345.

12. Woodruff, R. B. and S. F. Gardial. 1995. Know your customer: New approaches to understanding customer value and satisfaction. Cambridge, MA: Blackwell Publishers. 
TABLE 1: Listing of variables used for analysis and profiling marketing approaches to selling.

\begin{tabular}{|c|c|c|}
\hline Variables & Variable Description & Variable's Coding Scheme \\
\hline PRODEXP & $\begin{array}{l}\text { Sales force perception of } \\
\text { importance of product expert } \\
\text { marketing approach }\end{array}$ & $\begin{array}{l}\text { 1=least important; } 2=\text { =somewhat } \\
\text { important; 3=more important; } \\
\text { 4=most important }\end{array}$ \\
\hline APPLEXP & $\begin{array}{l}\text { Sales force perception of } \\
\text { importance of applications } \\
\text { expert marketing approach }\end{array}$ & $\begin{array}{l}\text { 1=least important; } 2=\text { somewhat } \\
\text { important; } 3=\text { =more important; } \\
\text { 4=most important }\end{array}$ \\
\hline RELSELL & $\begin{array}{l}\text { Sales force perception of } \\
\text { importance of relationship } \\
\text { or long-term management } \\
\text { building marketing approach }\end{array}$ & $\begin{array}{l}\text { 1=least important; } 2=\text { somewhat } \\
\text { important; } 3=\text { =more important; } \\
\text { 4=most important }\end{array}$ \\
\hline INDUS & $\begin{array}{l}\text { Type of industry } \\
\text { (Primarily service) }\end{array}$ & $\begin{array}{l}\text { 1=computer; } 2=\text { =financial; } \\
3=\text { =sporting goods; } 4=\text { =shipping; } \\
\text { 5=office equipment }\end{array}$ \\
\hline EDUC & Respondent's education level & $\begin{array}{l}\text { 1=high school; } 2=\text { associate } \\
\text { degree; } 3=\text { =bachelor of arts; } \\
4=\text { Bachelor of Science; } \\
\text { 5=masters; } 6=\text { =post-graduate } \\
\text { education }\end{array}$ \\
\hline EXPER & $\begin{array}{l}\text { Years of experience } \\
\text { With present company }\end{array}$ & $\begin{array}{l}1=\text { less than } 1 \text { year; } 2=1-3 \text { years; } \\
3=4 \text { to } 7 \text { years; } 4=\text { more than } \\
7 \text { years }\end{array}$ \\
\hline VOLUME & $\begin{array}{l}\text { Percentile of sales volume } \\
\text { individually compared to } \\
\text { sales force }\end{array}$ & $\begin{array}{l}1=\text { top } 10 \% ; 2=\text { =top } 25 \% ; \\
3=\text { top } 50 \% ; 4=\text { =bottom } 50 \% ; \\
5=\text { =uncertain }\end{array}$ \\
\hline SERVE & $\begin{array}{l}\text { Importance of servicing } \\
\text { existing accounts }\end{array}$ & $\begin{array}{l}\text { 1=least important; } 2=\text { somewhat } \\
\text { important; } 3=\text { =more important; } \\
\text { 4=most important }\end{array}$ \\
\hline YOBTAIN & $\begin{array}{l}\text { Importance of obtaining } \\
\text { new accounts }\end{array}$ & $\begin{array}{l}\text { 1=least important; } 2=\text { somewhat } \\
\text { important; } 3=\text { =more important; } \\
\text { 4=most important }\end{array}$ \\
\hline
\end{tabular}


Table 2: Two-way ANOVA measuring the relationships of PRODEXP with APPLEXP and RELSELL.

\begin{tabular}{lcccccc}
\hline $\begin{array}{l}\text { Source of } \\
\text { Variation }\end{array}$ & SS & df & MS & F & Prob. & Significance \\
\hline APPLEXP & 3.589 & 2 & 1.794 & 2.460 & 0.089 & NS \\
RELSELL & 0.546 & 3 & 0.182 & 0.250 & 0.861 & NS \\
APPLEXP & 21.449 & 3 & 7.150 & 9.802 & 0.000 & $\mathrm{~S}^{*}$ \\
X RESELL & & & & & \\
\hline EXPLAINED & 25.778 & 8 & 3.222 & 4.418 & 0.000 & $\mathrm{~S} *$ \\
\hline ERROR & 102.114 & 140 & & & & \\
\hline TOTAL & 127.892 & 148 & & & \\
\hline NOTE: * Denotes statistical significance at 0.01 level.
\end{tabular}

TABLE 3: One-way ANOVA measuring the relationship of PRODEXP with APPLEXP.

\begin{tabular}{lrrrrrl}
\hline $\begin{array}{l}\text { Source of } \\
\text { Variation }\end{array}$ & SS & df & MS & F & Prob. & Significance \\
\hline APPLEXP & 3.782 & 2 & 1.891 & 2.225 & 0.112 & NS \\
ERROR & 124.110 & 146 & 0.850 & & \\
TOTAL & 127.892 & 148 & & & \\
\hline NOTE: Results were found to be not statistically significant at the 0.05 level.
\end{tabular}


Table 4: One-Way ANOVA results associated with the relationship of PRODEXP with RELSELL.

\begin{tabular}{lrrrrrr}
\hline $\begin{array}{l}\text { Source of } \\
\text { Variation }\end{array}$ & SS & df & MS & F & Prob. & Significance \\
\hline RELSELL & 0.740 & 3 & 0.247 & 0.281 & 0.839 & NS \\
ERROR & 127.152 & 145 & 0.877 & & \\
TOTAL & 127.892 & 148 & & & \\
\hline NOTE: Results were found to be not statistically significant at 0.05 level.
\end{tabular}

NOTE: Results were found to be not statistically significant at 0.05 level.

TABLE 5: Forward step-wise regression analysis with VOLUME as the criterion variable.

\begin{tabular}{lcccc}
\hline Variables & Multiple R & $\mathbf{R}^{2}$ & $\mathbf{R}^{2}$ change & F-Ratio \\
\hline EXPER & 0.23169 & 0.05368 & 0.05368 & 7.31728 \\
SIZE & 0.31702 & 0.10050 & 0.04683 & 7.15098 \\
PRODEXP & 0.35195 & 0.12387 & 0.02336 & 5.98499 \\
YOBTAIN & 0.37764 & 0.14261 & 0.01875 & 5.23961 \\
RELSELL & 0.39928 & 0.15943 & 0.01681 & 4.74157 \\
EDUC & 0.41201 & 0.16975 & 0.01033 & 4.22550 \\
YEARS & 0.42049 & 0.17681 & 0.00706 & 3.77415 \\
SERVE & 0.42471 & 0.18038 & 0.00357 & 3.35623 \\
APPLEXP & 0.42831 & 0.18345 & 0.00307 & 3.02044 \\
\hline
\end{tabular}


TABLE 6: Pearson Correlation Coefficients of Marketing Approaches Versus Industrial Type, Education, and Experience.

Marketing Approach

PRODEXP

APPLEXP

RELSELL

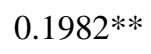

$0.1174 * * *$

$-0.0545$
$-0.1726 *$

0.0318

$0.1308^{* * * *}$
0.0439

0.0330

$0.1589 *$

NOTE: *denotes statistical significance at 0.05 level; **denotes statistical significance at 0.01 level; ***denotes approaching statistical significance at 0.05 level.

TABLE 7: Spearman Nonparametric Rank-Order Correlation Coefficients of Marketing Approaches Versus Industrial Type, Education, and Experience.

\begin{tabular}{lccc} 
Marketing Approach & Industrial Type & Education & Experience \\
\hline PRODEXP & $0.1877^{* *}$ & $-0.1673^{*}$ & 0.0513 \\
APPLEXP & $0.1135^{* * *}$ & 0.0207 & 0.0438 \\
RELSELL & -0.0638 & 0.0072 & $0.1659^{*}$
\end{tabular}

NOTE: * denotes statistical significance at 0.05 level; ** denotes statistical significance at 0.01 level; *** denotes approaching statistical significance at 0.05 level. 